\title{
AS MIL E UMA MORTES DE UM ESTUDANTE: FOTO-ÍCONES E HISTÓRIA FOTOGRÁFICA
}

\author{
A thousand and one deaths of a student: photo icons and \\ photographic history
}

Las mil y una muertes de un estudiante: foto íconos e historia fotográfica

\author{
ANA MARIA MAUAD ${ }^{*}$ \\ MAURICIO LISSOVSKYII ${ }^{\text {I** }}$
}

DOI: https://doi.org/10.1590/S2178-149420210102

'Universidade Federal Fluminense - Niterói (RJ), Brasil.

* Professora titular do Departamento de História da Universidade Federal Fluminense, pesquisadora do Laboratório de História Oral e Imagem da Universidade Federal Fluminense, do Conselho Nacional de Desenvolvimento Científico e Tecnológico e da Fundação de Amparo à Pesquisa do Estado do Rio de Janeiro (anammauad@gmail.com).

(D) https://orcid.org/0000-0001-8973-5238

"Universidade Federal do Rio de Janeiro - Rio de Janeiro (RJ), Brasil.

**Professor da Escola de Comunicação da Universidade Federal do Rio de Janeiro, pesquisador do Conselho Nacional de Desenvolvimento Científico e Tecnológico (mauricio.lissovsky@eco.ufrj.br).

(D) https://orcid.org/0000-0002-0734-790X

Artigo recebido em 23 de agosto de 2020 e aprovado para publicação em 5 de novembro de 2020 . 


\title{
RESUMo
}

0 estudo avalia a possibilidade de uma história fotográfica com base na noção de foto-ícone, que nos ajuda a observar como as imagens participam da história e conformam a experiência que temos dela. Seguindo a biografia, nem sempre linear, de uma imagem, acompanhamos neste artigo a trajetória da fotografia do estudante perseguido pela polícia. Produzida por Evandro Teixeira e publicada no Jornal do Brasil em 22 de junho de 1968, ela contrasta com outras imagens produzidas pela equipe fotográfica do Correio da Manhã, publicadas na mesma data e encontradas anos depois no arquivo do jornal inglês Daily Herald.

PALAVRAS-CHAVE: História Fotográfica; Foto-Ícones; Manifestação Estudantil, Brasil: 1968.

\begin{abstract}
This study evaluated the possibility of a photographic history from the notion of photo icons that helps us to observe how images make history and shape our experience of it. Following the trajectory, not always linear, of a photograph of a student pursued by the police, taken by Evandro Teixeira and published in Jornal do Brasil on June $22^{\text {nd }}, 1968$, in perspective to other images taken by the photographic crew of Correio da Manhã, published on the same day, and found years later in the archives of the English newspaper Daily Herald.
\end{abstract}

KEYWORDS: Photographic History; Photo Icons; Student Demonstration; Brazil: 1968.

\section{RESUMEN}

Este estudio evalúa la posibilidad de una historia fotográfica, desde la noción de foto íconos como imágenes que, disponiendo de una biografía, prescriben una trayectoria ni siempre lineal. Los foto íconos nos interesan no porque pueda haber una historia por detrás de las imágenes, sino porque las imágenes hacen historia y dan forma a la experiencia que tenemos de ellas. En este artículo seguimos la trayectoria de la fotografía de un estudiante realizada por Evandro Teixeira, y publicada en Jornal do Brasil, el 22 de junio de 1968, en perspectiva con otras imágenes producidas por el equipo fotográfico del Correio da Manhã, publicadas en la misma fecha, y encontradas años después en el archivo del periódico inglés Daily Herald.

PALABRAS CLAVE: Historia Fotográfica; Foto Íconos; Manifestación Estudantil; Brasil:1968. 


\section{DE OLHO NA HISTÓRIA}

A longo do século passado, a fotografia pública seguiu dois rumos: o da prática criavalorizava-se a expressão autoral, fosse no pictorialismo que perseguia padrões de representação artística, fosse, como mais tarde, em companhia das vanguardas artísticas, colocando em questão o próprio princípio realista. Já na segunda vertente, a fotografia associou-se à imprensa ilustrada e à produção de notícias, oferecendo-se como janela que se abria para o mundo, figurando-se o próprio "olho da história", na feliz expressão do fotógrafo da guerra civil norte-americana, Mathew Brady. Nesse contexto, a produção fotográfica novecentista assume práticas de registro social, documentando condições de vida, deslocamentos de população, conflitos e tragédias sociais. No cumprimento de sua vocação pública, a fotografia transmite mensagens e participa das disputas políticas, dando visibilidade às estratégias discursivas e representações de mundo dos atores.

A fotografia pública, posta em circulação por agências de produção de imagens, participa da formação da opinião, tal como ela ocorre em veículos de comunicação e órgãos do estado. É, portanto, suporte de agenciamento de uma memória pública que registra, retém e projeta no tempo histórico versões dos acontecimentos construídas por narrativas visuais e verbais, intertextuais e pluritemporais - pois coabitam nela o tempo do acontecimento, o tempo de sua transcrição narrativa e o tempo de sua recepção nos marcos de várias publicações (imprensa, museus, livros, apropriações artísticas, sites e memes na internet etc.). A fotografia pública intervém na constituição visual do espaço público nas sociedades contemporâneas, em compasso com as visões de mundo às quais se associa e, por seu próprio turno, engendra (Mauad, 2013).

Nessa perspectiva, o arquivo fotográfico do Daily Herald interessa-nos particularmente. Sua regularidade ao longo de décadas, bem como seu alinhamento à esquerda do espectro político, traduziram-se em um compromisso editorial que valorizava notícias internacionais para uma audiência local, integrando-se por meio de serviços de variadas agências de notícias ao sistema global de comercialização e difusão de registros fotojornalísticos. Com relação à América do Sul, essa cobertura é especialmente significativa no período entre as décadas de 1930 e 1960.

A mera comparação da quantidade de imagens arquivadas relativas a cada país sul-americano nos sugere uma geopolítica da visualidade. Brasil e Argentina, no período de cobertura do jornal, ocupavam lugares de destaque nas relações internacionais, e os respectivos cenários políticos colocavam em relevo a agenda trabalhista. É notável como se destaca nas pastas relativas a Brasil, Chile e Argentina o volume de fotografias sobre "revoluções, revoltas 
e manifestações". Esse conjunto recebe um impulso especial nos anos 1960, quando Chile e Argentina são contemplados com muitas imagens de manifestações contra os interesses dos Estados Unidos na América do Sul1. Algumas delas têm, naquela época e ainda hoje, um denso referencial icônico, capaz de sintetizar fotograficamente a experiência histórica de seu tempo. São foto-ícones.

Na história fotográfica, foto-ícones representam a condensação do tempo histórico em um acontecimento. Sua exploração nos permite investigar não apenas o contexto e 0 sentido público que assumem no tempo de sua realização, mas sua permanência na memória, suas transcrições e apropriações futuras. A relação entre a imagem fotográfica e a produção do fato histórico apresenta-se como expressão visual de uma sensibilidade histórica coletiva (Mauad, 2008a; 2008b), mas convém assinalar que a noção de foto-ícone não é consensual nos estudos acerca da fotografia pública. Nos Estados Unidos, onde essa questão ganhou relevo no campo dos estudos sobre a relação entre cultura pública e meios de comunicação, os foto-ícones são associados à prevalência da fotografia humanista e à difusão dos ideais da democracia liberal.

Duas posições merecem destaque. A primeira, engajada e crítica da defesa incontestável dos valores da democracia liberal, é formulada por Blake Stimson; a segunda, tributária da tradição crítica liberal que valoriza a cultura pública e sua capacidade de promover 0 consenso, pode ser observada nos escritos de Lucaites e Hariman. Blake Stimson atribui à fotografia, principalmente àquela produzida após a Segunda Guerra Mundial, o papel de eixo ordenador das demandas coletivas em torno da nação como comunidade de sentido, na qual se compartilham valores que podem ser estendidos a toda a humanidade. Segundo esse autor, a fotografia viria a se tornar o espaço comum em que se consolidariam as identidades sociais, assumindo o papel antes ocupado pela nação no imaginário ocidental e dando origem a uma "nação fotográfica" (Stimson, 2007). Já na segunda posição, assumida por Harriman e Lucaites, a fotografia - na sua expressão de foto-ícone - caracteriza-se pela capacidade de comunicar e mobilizar valores associados à democracia liberal e à cultura pública, provendo modelos performativos para o exercício da cidadania (Hariman e Lucaites, 2007). Estes últimos definem foto-ícones como imagens que aparecem na imprensa, nas mídias eletrônica e digital, amplamente reconhecidas e lembradas por representarem eventos historicamente significativos. Ao circular por variados meios, provocam respostas emocionais na audiência e a identificação imediata com os sujeitos envolvidos. Embora os foto-ícones disseminados pelo fotojornalismo não possuam valor universal, mobilizam ideais de cidadania, de igualdade de direitos e de obrigações coletivas. Em resumo, figuram princípios comuns para a construção da identidade coletiva na cultura pública liberal-democrática (Hariman e Lucaites, 2007: 28). 
Ambas as posições visavam compreender a formação da cultura pública na democracia norte-americana moderna. Esses modelos, no entanto, não se mostram inteiramente adequados à compreensão de outras situações históricas. No âmbito do presente estudo, que se volta para a possibilidade de uma história fotográfica brasileira, o foto-ícone é pensado como dispondo de uma biografia, cuja trajetória nem sempre é linear². Os foto-ícones nos interessam aqui não porque pode haver uma história por trás das imagens, que as enquadra e explica, mas porque imagens fazem história e conformam a experiência que temos dela.

\section{O ARQUIVO FOTOGRÁFICO DO DAILY HERALD E A SOUTH AMERICA}

m oportunidades distintas, em 2007 e 2018, entramos em contato com o arquivo fo-
tográfico do Daily Herald no Insight, setor do Museu de Ciência e Mídia, localizado em Bradford, Inglaterra. Encontramos lá um conjunto importante de fotografias sob a rubrica South America, subdividido em países, cada qual com pastas organizadas segundo uma lógica temática. No ano passado, decidimos começar a explorar esse material partindo de algumas premissas de investigação:

- que imagens do Brasil as agências e jornais estrangeiros supunham relevantes ou de interesse para o público europeu, particularmente o inglês?;

- que fotografias desconhecidas em seu país de origem esse arquivo abrigaria?; e

- que narrativas ou perspectivas alternativas suscitariam essas fotografias a respeito da iconicidade e noticiabilidade internacionais de eventos sul-americanos no século $X X$, assim como que valores, preconceitos e pressupostos culturais e ideológicos impulsionaram sua circulação?

O Daily Herald foi originalmente publicado, entre janeiro e abril de 1911, como um boletim de greve organizado, entre outros, pelo sindicalista Ben Tillett e pelo político socialista George Lansbury. Este último veio a ser editor do jornal diário que circulou entre 1912 e 1964³ . O jornal foi um dos importantes apoiadores da London Society of Compositors em sua campanha pelo estabelecimento da semana de 48 horas de trabaIho. Durante o racionamento de alimentos de 1917, publicou o artigo intitulado "How they starve at the ritz", no qual o repórter Francis Maynell relatava ter jantado disfarçado no famoso hotel londrino e descrevia como o racionamento havia (ou antes, não havia) afetado os jantares da classe dominante. Mayneel, escrevendo anonimamente, narrou em detalhes como o famoso creme inglês jorrava em abundância apesar do racionamento de 
leite, e como as refeições eram fartas e bem servidas. 0 artigo foi reimpresso e distribuído em forma de panfleto para as classes trabalhadoras.

Nos primeiros anos de existência, o Daily Herald enfrentou muitas dificuldades financeiras e ao longo da primeira Grande Guerra se tornou semanal, retomando a publicação diária um ano após o fim do conflito, em 1919. 0 jornal posicionou-se firmemente contra a guerra e contra contra a posição antibolchevique do governo britânico. Em 1920, Lasnbury associou o Herald ao Partido Trabalhista e o jornal tornou-se órgão oficial dos congressos sindicais. Ao longo de sua existência, o Daily Herald acolheu fotografias dos principais eventos internacionais, contando em sua rede de forncecedores com as principais agências de notícias do período. Algo de seu viés editorial de esquerda, trabalhista e social-democrata, transparece na cobertura jornalística assim como na formação de seu arquivo fotográfico.

0 Brasil é o país sul-americano com o maior número de fotografias no arquivo, distribuídas em 14 pastas temáticas: Brasília; Crimes; Defesa; Expedições; Incêndios; Indústria e Energia; Lugares - Miscelânea; Miscelânea; Religião; Revoluções, Revoltas e Manifestações; Rio de Janeiro; Rio de Janeiro - Maracanã - Copa de 1950; Transportes e Acidentes ${ }^{4}$. As legendas nem sempre são claras, falhando em identificar com precisão eventos e/ou locais. 0 crédito padrão remete apenas à agência de notícias fornecedora da imagem e o autor da foto quase nunca é identificado (Lissovsky e Mauad, 2019).

0 segundo país da América do Sul com maior número de fotografias no arquivo é a Argentina, com 13 pastas: Agricultura - Indústria; Ciência; Aviação; Combustível - Energia; Defesa - Marinha; Defesa - Miscelânea; Esporte; Lugares - Buenos Aires; Estradas - Transporte; Lugares - Miscelânea; Miscelânea; Polícia; e Revoltas. 0 Chile conta com sete pastas: Defesa, Esportes; Lugares - Miscelânea; Miscelânea; Revoltas e Manifestações; Santiago; e Terremoto (1960). Por fim, Uruguai tem apenas duas pastas.

Uma radiofoto originária do Chile, distribuída pela Associated Press, pode nos servir aqui de exemplo do entrecruzamento de sensibilidades e narrativas que conformam a historicidade de uma fotografia (Figura 1). Nela, uma bandeira norte-americana é queimada por manifestantes em 19 de junho de 1954, em Santiago. Podemos observar que o fotógrafo buscou incluir, além do evento principal, um cartaz que dá ao gesto um significado que transcende as circunstâncias locais. Escrito à mão, com claro sentido de urgência, lemos: "Pueblo chileno con Guatemala". Sob o título "Anti-USA demonstration in Chile", o verso da fotografia informa:

Chilenos queimam uma bandeira norte-americana na Praça Central de Santiago durante uma manifestação na noite de 19 de junho. 


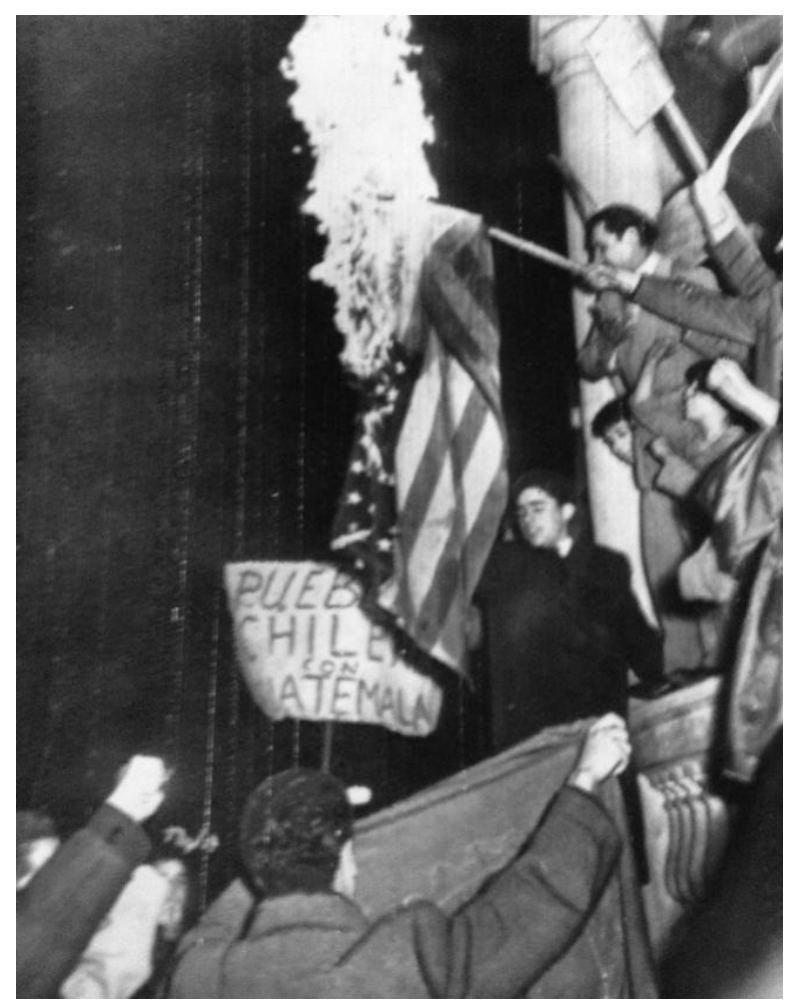

Figura 1 - Manifestação em Santiago, Chile, em 19 abr. 1954. Fonte: The Daily Herald Archive, 1983-5236.

Estudantes e trabalhadores se manifestaram em apoio ao governo do presidente Jacobo Arbenz Guzman da Guatemala.

Durante a demonstração uma efígie do presidente Eisenhower dos EUA também virou fumaça e as janelas do jornal "El Mercurio" foram apedrejadas. (The Daily Herald Archive, 1983-5236).

0 ato de queimar a bandeira dos Estados Unidos, que se tornou lugar-comum em manifestações estudantis latino-americanas nas décadas de 1960 e 1970, ainda era raro nos anos 1950. No dia anterior, em 18 de junho, tinha sido deflagrado um golpe de estado, patrocinado pela Central Intelligence Agency (CIA) (o primeiro de uma série de golpes no continente), contra o presidente da Guatemala, Jacobo Arbenz. Apesar de ter sido eleito democraticamente, ele vinha sendo considerado pela inteligência americana uma cabeça de ponte do comunismo na América Central. Um pequeno exército de 400 homens liderados por um coronel guatemalteco exilado foi suficiente para tomar o poder em pouco mais de uma semana. Apesar de as manifestações no Chile terem ocorrido durante vários dias (uma passeata em 24 de junho, por exemplo, 
contou com a participação do poeta Pablo Neruda), essa é a única fotografia desses acontecimentos que, até onde sabemos, ganhou algum destaque internacional ${ }^{5}$.

Em 24 de junho de 1954, é publicada pelo New York Herald Tribune. 0 Departamento do Estado já tinha recebido anteriormente informes produzidos pela embaixada estadunidense no Chile que relatavam que, enquanto a bandeira ardia, milhares de estudantes reunidos na Plaza de Armas ovacionavam e gritavam: "Unir nossas forças e cerrar fileiras para derrotar a agressão contra a Guatemala" (Hove, 2007: 636.) As manifestações haviam sido convocadas por uma organização suprapartidária criada meses antes, os Amigos da Guatemala - e que inspirou grupos similares em El Salvador, Cuba e México. Para algumas das forças políticas que dela participavam, tratava-se da defesa da democracia no continente, enquanto, para outros, tratava-se de impulsionar reformas nas respectivas sociedades (particularmente na estrutura fundiária) e do fim da sujeição latino-americana aos interesses de corporações estrangeiras, como a malfadada United Fruit Company. Mas os congressistas e diplomatas norte-americanos - em um contexto no qual as audiências da Comissão McCarthy mobilizavam a opinião pública - viam, pela primeira vez, sua bandeira nacional em chamas em protestos políticos que reuniam multidões. Do seu ponto de vista, era o sinal evidente de que havia uma ameaça comunista pairando sobre o Chile (Hove, 2007: 640). Os punhos cerrados dos estudantes (e, digamos sub-repticiamente, a bandeira da Central Única dos Trabalhadores do Chile, fundada no ano anterior, que vemos pelo avesso em primeiro plano) podem ter contribuído para essa leitura. A reação às manifestações nos meios governamentais norte-americanos foi tão furiosa que o subsecretário de Relações Exteriores do Chile convocou o representante da Associated Press em Santiago e repreendeu-o por mandar a fotografia da bandeira queimando para Nova York (Hove, 2007).

Segundo os jornais norte-americanos, os protestos em Santiago haviam sido "violentos" - ainda que as únicas vítimas conhecidas, além da bandeira da União, tenham sido as janelas do jornal conservador El Mercurio. Para os trabalhadores chilenos, por sua vez, as manifestações foram a oportunidade de aquecer a flâmula de sua nova central sindical nas chamas da solidariedade internacional. 0 potencial icônico de uma imagem carrega consigo sempre uma ambivalência de sentimentos e uma ambiguidade de sentido, uma encruzilhada do destino que é também a dos acontecimentos históricos. Para o jovem médico Ernesto Guevara, que estava na Guatemala por ocasião do golpe, a solidariedade revolucionária latino-americana começa com sua rejeição à queda de Arbenz. Já para os Estados Unidos da guerra fria, a disputa pelo Chile - e a concomitante caracterização do senador socialista Salvador Allende como ameaça a seus interesses - é despertada por uma bandeira em chamas na noite de Santiago. 


\section{UMA “SEXTA-FEIRA SANGRENTA” NO RIO DE JANEIRO}

o contexto brasileiro, nosso foco inicial de pesquisa são as fotografias da década de
1960, particularmente a partir da instalação da ditadura militar, em 1964. Uma imagem relativa ao treinamento de uma unidade antiguerrilha do exército logo chamou nossa atenção, tendo sido objeto de um estudo preliminar. Aqui nos dedicamos às imagens da "sexta-feira sangrenta" episódio de repressão policial ao movimento estudantil que, em 21 de junho de 1968, contestava o regime nas ruas do Rio de Janeiro ${ }^{6}$. Nesse caso, nossa primeira surpresa não foi o que encontramos no arquivo, mas o que não estava lá. Faltava uma imagem: exatamente a mais mais conhecida no Brasil — não apenas entre as que foram feitas naquele dia fatídico, mas seguramente a mais icônica das fotografias de repressão aos estudantes pela polícia nos tempos da ditadura (Figura 2).

Seu autor, o fotógrafo Evandro Teixeira, nasceu na Bahia mas foi no Rio de Janeiro que consolidou a sua carreira. Em 1963, ingressou no Jornal do Brasil, prestigiado veículo da imprensa carioca em que a fotografia era muito valorizada, garantindo ao fotógrafo autonomia no registro. Essa fotografia foi publicada na primeira página, como evidência contundente da violência policial do regime militar imposto ao Brasil em 1964. A "sexta-feira sangrenta" coroava uma semana de manifestações e confrontos entre a Polícia Militar, o movimento estudantil e a população. Na quarta-feira, 19 de junho, os estudantes que protestavam contra os acordos entre o Ministério da Educação e a United States Agency for International Deve-

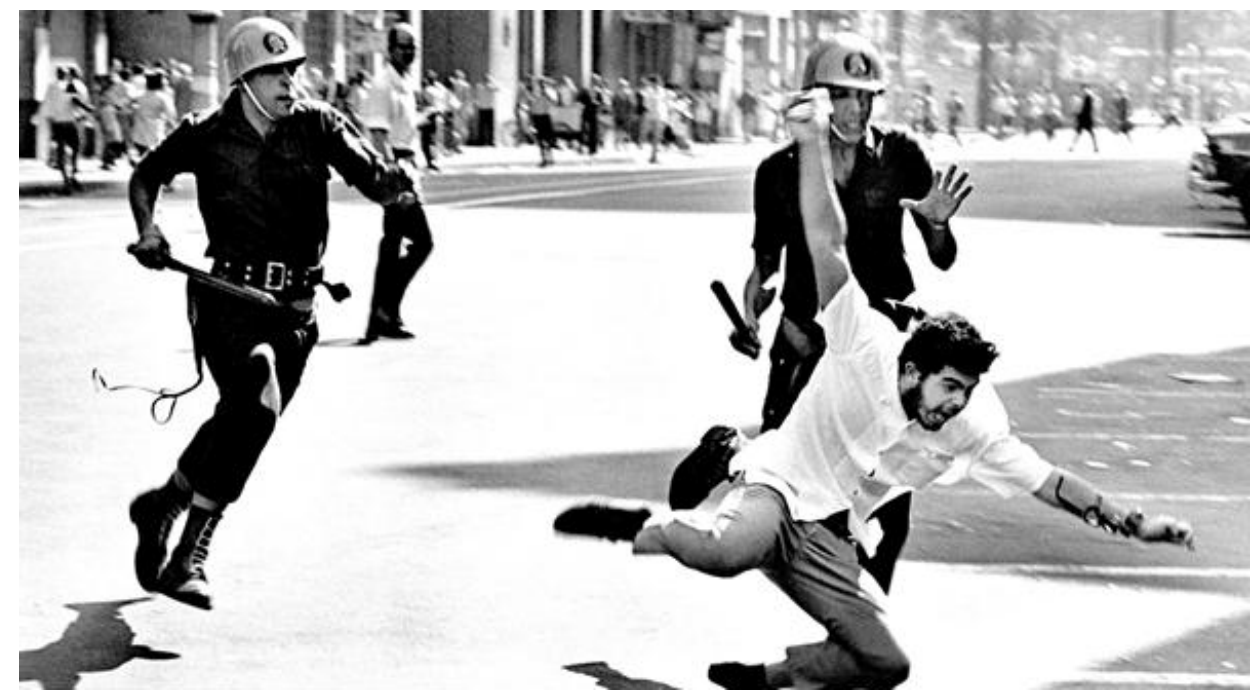

Figura 2 - Caça ao estudante, Sexta-Feira Sangrenta, publicada no Jornal do Brasil, p. 1, 22 jun. 1968. Fonte: Arquivo Evandro Teixeira/Instituto Moreira Salles. 
lopment - conhecidos como acordo MEC-USAID ${ }^{7}$ - e a política educacional para o ensino superior do governo haviam sido duramente reprimidos. No dia seguinte, quinta-feira, 20 de junho, convocaram uma assembleia no campus da Praia Vermelha da Universidade Federal do Rio de Janeiro (UFRJ) para discutir o fechamento do regime e a interrupção do diálogo entre o Ministério da Educação e as lideranças do movimento estudantil. Foram cercados pela polícia militar, detidos e transferidos para um estádio de futebol próximo, onde 400 presos foram mantidos aterrorizados e incomunicáveis por muitos horas.

Na manhã do dia 21, sexta-feira, uma nova passeata, agora em protesto contra a repressão, paralisou o centro do Rio. Os estudantes reagiram às investidas da polícia, enfrentando a cavalaria com rolhas e bolas de gude que faziam os cavalos tombar. A população apoiou os jovens e também atacou a polícia com pedras. Do alto dos prédios, objetos foram atirados sobre os soldados. A polícia reagiu com tiros, e bombas de gás lacrimogênio foram lançadas de helicópteros. Desde o fim da manhã e ao longo da tarde, o conflito espalhou-se por uma extensa área do centro, deixando um saldo de 28 mortos - 27 civis e um policial, este último atingido por um balde de cimento jogado de um edifício em construção — , centenas de feridos, mais de mil pessoas presas e vários veículos incendiados.

A sociedade civil tomaria as ruas, em apoio aos estudantes, em 26 de junho de 1968. Era a famosa "passeata dos 100 mil", igualmente fotografada por Evandro Teixeira. Dois importantes jornais do Rio de Janeiro cobriram esses eventos extensivamente, Correio da Manhã e Jornal do Brasil. Ambos haviam tido papel de destaque na conformação do moderno fotojornalismo brasileiro por introduzirem editorias de fotografia em suas redações e conferir autonomia de ação a suas equipes (Louzada, 2013). o fotógrafo Erno Schneider teve participação decisiva na reformulação da prática fotográfica em ambos os jornais. Erno nasceu no estado do Rio Grande do Sul e iniciou sua carreira de fotógrafo nesse estado. Valendo-se de contatos políticos, mudou-se para o Rio de Janeiro no fim dos anos 1950, sendo contratado pelo Jornal do Brasil. Foi como profissional desse veículo, a propósito, que conquistou o prêmio Esso de Fotojornalismo em 1962 (primeira vez em que a categoria fotojornalismo foi incluída), com a famosa imagem de um retorcido presidente Jânio Quadros (Mauad, 2008c).

A novidade fundamental implementada por Erno Schneider consistia em liberar os fotógrafos da função de acompanhantes do repórter para tornarem-se fotojornalistas de pleno direito. Construíram-se estratégias, apoiadas nessa autonomia, que visavam plasmar visualmente os acontecimentos, valorizando os sujeitos em ação no seu contexto, elaborando narrativas visuais e buscando imagens de impacto que se impusessem às primeiras páginas. Em decorrência desses procedimentos, grandes eventos davam origem à composição de páginas gráficas em que as imagens recebiam somente um título e uma breve legenda. 
Mas a grande aspiração do fotojornalismo era a produção de foto-ícones, imagens plenas de sentido que sobrevivessem no tempo, tornando-se âncoras visuais dos acontecimentos contemporâneos (Mauad, 2008a).

Na fotografia da "sexta-feira sangrenta", com a qual Evandro Teixeira conquistou um lugar na primeira página do Jornal do Brasil, os elementos que garantiram sua permanência na memória pública são fáceis de reconhecer. Os antagonistas estão bem representados por seus tipos, policiais e estudante com os respectivos apetrechos: cassetetes e botas de um lado, óculos e barba do outro. 0 conflito, condensado em três personagens, demonstra tão bem a superioridade da força policial e a violência da ação repressiva que quase passa despercebida a mancha de uma pedra na mão direita do estudante. Mas sua qualidade decisiva é que os personagens estão voltados para nós, exibindo seus rostos, suas feições e suas emoções, 0 que nos diferencia de meros leitores de jornal. Graças a essa frontalidade, somos testemunhas de um acontecimento que não se desenrola em uma tela ou palco e que apreciamos em segurança, mas de um que vem em nossa direção.

A fotografia de Evandro não está, porém, isenta de uma dimensão espetacular. A postura acelerada dos três protagonistas contrasta com o passo relativamente tranquilo das demais pessoas. Apesar de haver um transeunte que observa a ação em contraplano, ele apenas reitera que é diante de nós e para nós que ela se desenvolve. A força do pathos sobrepõe-se aqui à informação e à representação. É possível "ouvir" o grito do estudante, perceber o esforço de um dos soldados que o persegue, constatar a surpresa do outro que procura evitar a trombada com o jovem que cai. Se a fotografia interrompe a ação nesse momento singular em que dois corpos praticamente não tocam o chão, trata-se, a rigor, da interrupção de uma interrupção, pois o estudante acabara de sustar abruptamente sua fuga (tropeçou ou foi derrubado?), pois a inércia dos óculos ainda prolongava a trajetória sustada. Se a causa imediata da queda não pode ser plenamente assegurada, menos ainda sua consequência. Teria o estudante sido capturado e preso? Espancado no chão? Teria sobrevivido ao massacre ou esses óculos que saltam do rosto prenunciam o estilhaçamento de seu corpo no asfalto?

\section{A "SEXTA-FEIRA SANGRENTA" NO ARQUIVO DO DAILY HERALD/THE SUN}

\footnotetext{
omo dissemos, a mais célebre das fotografias do conflito nas ruas do Rio de Janeiro não constava dos arquivos na Inglaterra. Mas o 21 de junho de 1968 estava representado por duas outras imagens que pareciam dar continuidade à cena registrada por Evandro Teixeira (Figura 3). Na legenda datilografada que acompanha a fotografia, lê-se:
} 


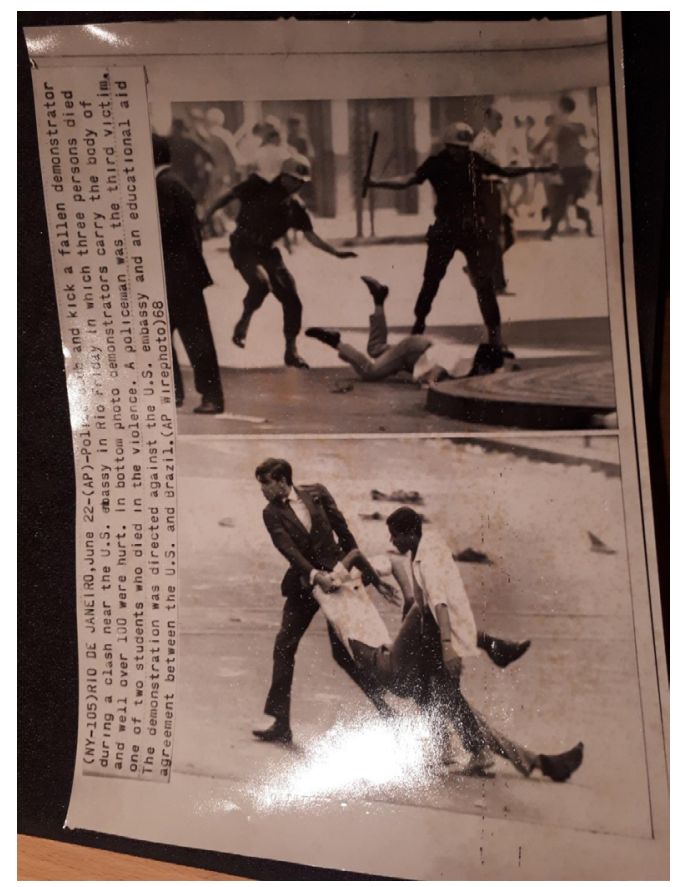

Figura 3 - Cópia da fotografia encontrada na pasta "Riots, Revolutions and Demonstrations". Fonte: Arquivo do jornal Daily Herald, Museum of Media and Science, Bradford, United Kingdom .

(NY-105) RIO DE JANEIRO, Junho 22 - (AP) — Policiais golpeiam com cassetete e chutam um manifestante caído durante um confronto perto da embaixada dos Estados Unidos no Rio. Uma sexta-feira na qual três pessoas morreram e mais de cem foram feridas. Na foto abaixo, manifestantes carregam o corpo de um dos dois estudantes que morreram na violência. Um policial foi a terceira vítima. A manifestação era contra a embaixada dos EUA e um acordo educacional entre os EUA e o Brasil (AP Wirephoto) 68.

Raramente vistas hoje em dia no Brasil, ambas foram publicadas por ocasião dos eventos. A foto superior, na primeira página do jornal Correio da Manhã (Figura 4) de 22 de junho de 1968, traz a seguinte legenda: "Massacre poderia ser a palavra de ordem para o soldados da Polícia Militar e agentes do DOPS, que agiram sem piedade, atacando crianças, jovens e velhos". A foto inferior foi publicada na página 9 do mesmo jornal (Figura 5), juntamente com outra de corpos no chão, em página gráfica onde se lia uma legenda continuada para as duas fotografias: "Dados como mortos, os desconhecidos jaziam no meio da rua" e "Logo depois eram retirados sem possibilitar a sua identificação" (ano 1968, edição 23.067 - 22 de junho de 1969 - Correio da Manhã). 


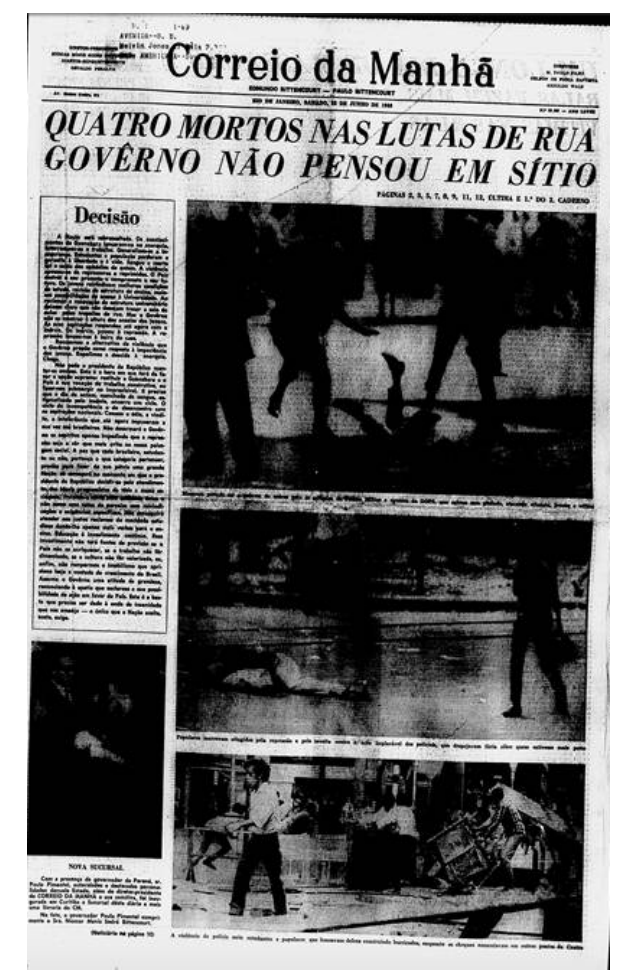

Figura 4 - Primeira página do Correio da Manhã, 22 jun. 1968 Fonte: Biblioteca Nacional, Hemeroteca Digital.

A equipe do Correio da Manhã, na época, era composta de Erno Schneider, Manoel G. da Costa, Milton Santos, Rodolfo Machado, Sebastião Marinho, Rubens Seixas, Gilmar Santos e Omar Gallo. A autoria dessas duas imagens não é conhecida. Foram transmitidas pela Associated Press à sede em Nova York e desta para Londres sem o crédito dos fotógrafos e a identificação do veículo que as produziu. Igualmente, nenhuma das dezenas de fotografias publicadas pelo jornal brasileiro naquela edição teve creditada sua autoria ${ }^{9}$.

No verso da ampliação da foto da capa encontrada no Arquivo Nacional, local de guarda do acervo de fotografias do jornal Correio da Manhã, confirma-se que a fotografia foi creditada a princípio a Erno, mas o crédito foi riscado e atribuído genericamente à equipe do jornal. Além disso, observa-se a data e a localização da tomada da fotografia. Sua prova arquivada permite uma visualização mais clara da cena, com destaque para o corpo tombado e as pernas soltas terminando o movimento de queda. A ideia de suspensão reforça-se pela pose dos dois soldados que se detêm diante da queda inesperada do corpo. A foto publicada segue as marcações de corte do verso (Figuras 6 e 7). 


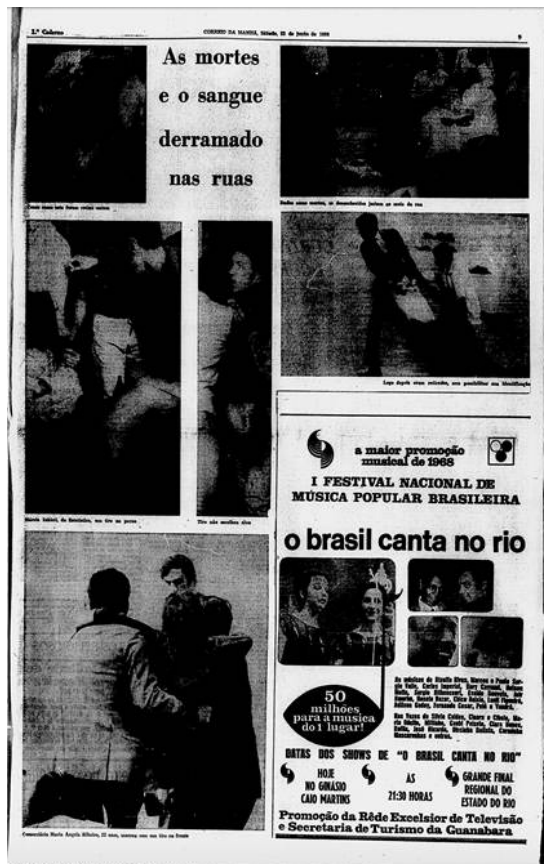

Figura 5 - Correio da Manhã, p. 9, 22 jun. 1968 Fonte: Biblioteca Nacional, Hemeroteca Digital.

A agência Associated Press, no entanto, introduz alguns elementos importantes por ocasião da distribuição da imagem. Tal como no caso da fotografia das manifestações em Santiago, o suposto interesse internacional do evento é caracterizado pelo fato de os acontecimentos terem se dado "perto da embaixada dos Estados Unidos", com o objetivo de protestar contra um "acordo educacional" com aquele país. Não há nenhuma bandeira norte-americana queimando, mas 14 anos depois da intervenção na Guatemala os protestos contra os Estados Unidos na América Latina não constituem mais novidade e não precisam de evidências adicionais para a mídia internacional.

Mas há outros elementos de contraste que nos deviam chamar a atenção. Na fotografia chilena de 1954, a legenda vai enumerando acontecimentos externos à imagem, de modo que uma leitura de crescente violência seja possível (uma leitura que políticos, oficiais de inteligência, funcionários do Departamento de Estado e editorialistas de jornais como o New York Times irão efetivamente fazer): queima-se a bandeira, a efígie do presidente vira fumaça e as vidraças de um jornal são apedrejadas. No caso das manifestações em 1968, no Rio de Janeiro, não há necessidade de se sugerir violência, pois as imagens falam por si. 


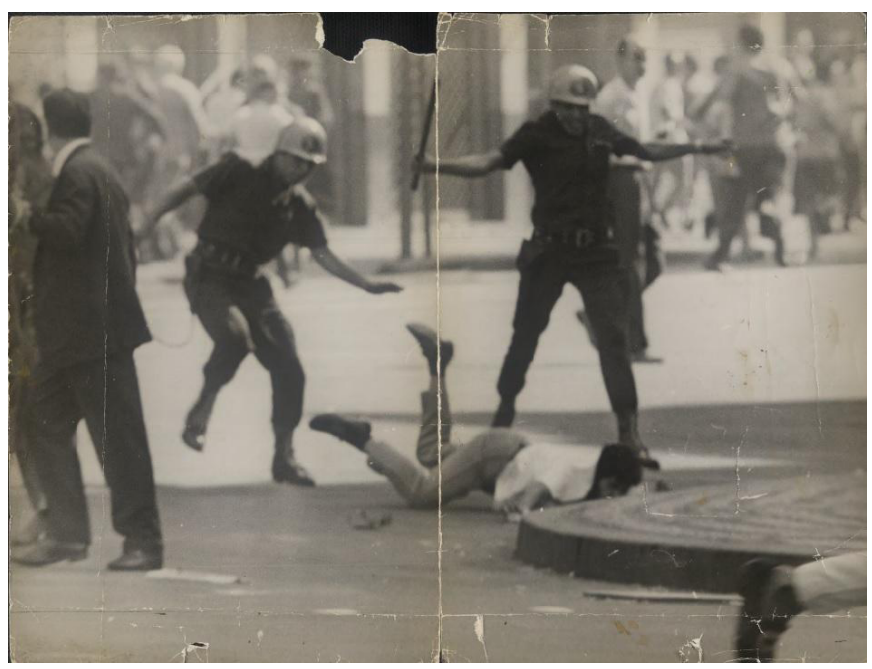

Figura 6 - PH FOT 229_84.

Fonte: Acervo Correio da Manhã, Arquivo Nacional.

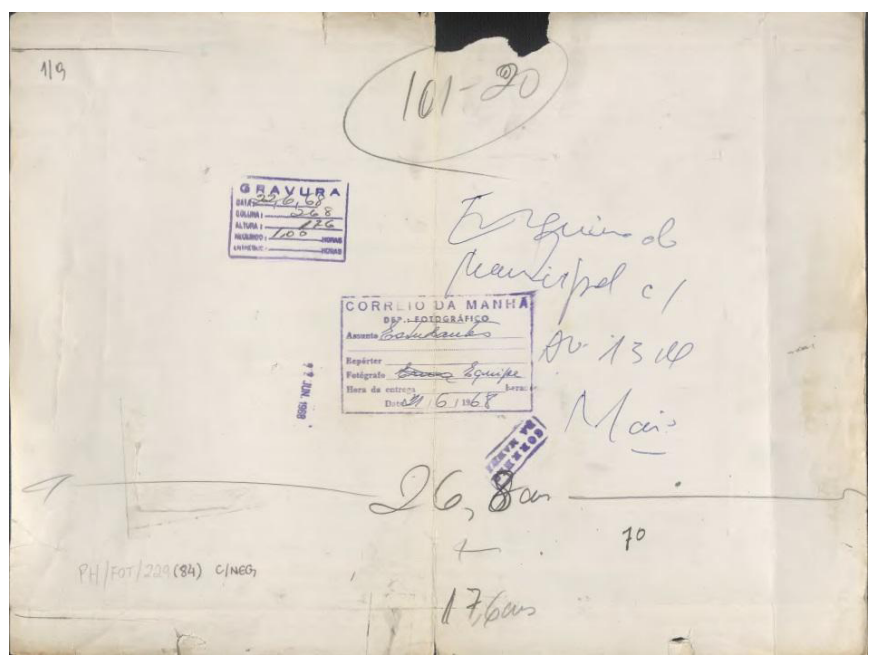

Figura 7 - PH FOT 229_84_V.

Fonte: Acervo Correio da Manhã, Arquivo Nacional.

Dois procedimentos, porém, agregam valor de notícia a elas. 0 primeiro é sua articulação em uma narrativa em dois tempos, sustentada pela unificação da legenda: no primeiro tempo, policiais agridem um estudante caído; no segundo, o corpo de um estudante é carregado por manifestantes. A unificação da legenda confere continuidade às imagens, sugerindo, sem enunciá-lo propriamente, que o estudante agredido na foto de cima é o mesmo cujo corpo 
está sendo carregado na foto de baixo. Ao enfeixá-las em uma só narrativa, como se um mesmo fotógrafo tivesse acompanhado os acontecimentos, reforça-se a leitura atribuída a cada uma delas individualmente. Como veremos adiante, ambas as interpretações nos parecem bastante problemáticas.

No Correio da Manhã, como assinalado, as fotografias não foram publicadas em sequência, mas bem distantes uma da outra: na primeira página, o estudante caído; na página 9, o corpo carregado. A legenda utilizada pelo jornal para a primeira tem caráter genérico, tratando-a como ilustração da violência policial, caracterizada como um "massacre" que se teria abatido "sem piedade" sobre "crianças, jovens e velhos". Nenhuma referência é feita a cassetetes e chutes sendo perpetrados naquele momento contra um estudante caído. Já com relação à segunda imagem, a discrepância é ainda maior: enquanto para a AP se trata do corpo de um estudante levado por manifestantes, o jornal brasileiro é propositadamente vago, dando margem a muitas suspeitas, ao informar que se trata de um "desconhecido", retirado "sem possibilitar identificação". Sabemos que a reação dos policiais naquele dia foi tão violenta quanto aleatória, que eles atiraram e surraram a esmo, irados com a adesão popular aos estudantes e com os objetos que eram jogados sobre eles do alto dos prédios. Entre os mortos, feridos e presos no dia, muitos não eram estudantes e vários, alegou-se na época, nem estavam participando dos protestos. A legenda do jornal não apenas reforça o caráter brutal da reação policial — irracional e indiscriminada — - mas insinua um esforço para ocultar suas consequências. Os jornalistas que acompanhavam os acontecimentos tinham claro que aquele não era o tipo de conflito em que os inimigos retiram seus "tombados em batalha" nos momentos de trégua. Não havia, naquela tarde, "terra de ninguém". A continuidade entre essas duas imagens, elaborada por ocasião de sua distribuição pela Associated Press, apoia-se em um tipo de narrativa heroica comum ao imaginário literário e cinematográfico e que já pertence ao repertório dos leitores. Supõe-se que essa narrativa seja pregnante o bastante para que se ignore que a fotografia do estudante caído foi feita do rés do chão, enquanto a do corpo sendo carregado foi tirada de um andar superior, provavelmente da própria redação do jornal.

A continuidade entre as fotografias distribuídas pela Associated Press é sobretudo imaginária. Por outro lado, a continuidade entre as fotografias das primeiras páginas do Jornal do Brasil e do Correio da Manhã é real. Há de fato uma diferença de pouquíssimos segundos entre elas. Evandro Teixeira está próximo à ação, enquanto o fotógrafo do Correio da Manhã, um pouco mais distante, à direita dele, acompanha a cena com o auxílio de uma teleobjetiva. Há vários marcadores temporais disponíveis nos quadros. 0 mais significativo, por não participar diretamente do conflito, é o transeunte que atravessa a rua observando a perseguição: ele mal chega a concluir um segundo passo entre uma fotografia e outra. 
Consistentemente, o estudante que caía agora já atingiu o solo. Os óculos ficaram para trás e a inércia agora é das pernas que insistem em seguir seu voo quando o peso do tronco e da cabeça não mais o permitem. Talvez se tenham passado dois segundos, no máximo três. 0 soldado mais próximo, que tinha a mão espalmada à frente, agora abre os braços para recuperar o equilíbrio. Já o soldado que corria pela esquerda pressiona fortemente o chão com o pé para brecar repentinamente a corrida. Os relatos do dia dão conta que, depois de dispersos, os manifestantes conseguem reorganizar-se em barricadas em várias ruas do Centro. Nesse momento, enquanto a cavalaria é lançada contra elas, policiais a pé formam grupos de quatro ou cinco para perseguir manifestantes desgarrados. A cena fotografada remete a esse contexto. Entre a fotografia do Jornal do Brasil e a do Correio da Manhã não houve tempo para as cassetadas e chutes relatados na legenda da Associated Press. Poderiam ter ocorrido antes, tendo o estudante escapado momentaneamente do ataque? Ou deram-se depois que ele caiu? A fotografia enviada ao Daily Herald está longe de ser evidência de uma coisa ou outra.

\section{FOTO-ÍCONES E EVIDÊNCIA HISTÓRICA}

lém do fotógrafo do Correio da Manhã, outro, de O País, também teve sua câmera destruí-
da. Mesmo assim, não faltam registros fotográficos da Sexta-Feira Sangrenta, evidenciando a inepta brutalidade e o sadismo ressentido de forças policiais que teriam recebido autorização para atuar com violência irrestrita naquela tarde. Os primeiros tiros partiram da guarnição constituída de um cabo e um soldado e postada junto à sede da embaixada norte-americana. As vidraças do edifício foram quebradas pelos estudantes e o centro da cidade tornou-se, literalmente, um campo de batalha entre forças claramente desiguais. A opção da Associated Press foi elaborar uma narrativa visual fictícia e, a despeito disso, fiel aos acontecimentos. Sua veracidade não se apoia apenas no que está efetivamente registrado nas fotografias enviadas ao Daily Herald, mas em uma história que o público já conhece por antecipação.

A fotografia de Evandro Teixeira, por sua vez, depende bem menos de uma corroboração exterior à imagem. Uma simples pesquisa de imagens no Google sobre a "sexta-feira sangrenta" demonstra-o com clareza: somos remetidos a diversas ocorrências dela e nenhuma vez às fotografias do Correio da Manhã distribuídas pela Associated Press. De fato, a "caça ao estudante" está entre as imagens mais utilizadas para ilustrar matérias jornalísticas, sites na internet e livros didáticos de História. Sua difusão está fortemente associada à memória gráfica da ditadura militar brasileira (1964-1985), que tende a reduzi-la, imaginariamente, a um conflito entre militares, de um lado, e estudantes, intelectuais e artistas, de outro (Lissovsky e Aguiar, 2016: 367-368). 
Mas, como todo foto-ícone, sua biografia de sucesso depende de dois aspectos que reforçam a capacidade de dramatizar o conflito que caracteriza um processo ou acontecimento: o primeiro é o pertencimento a uma série de imagens similares relativas a outros eventos, cuja leitura é facilitada pela reiteração; e o segundo é ser portadora de uma ambiguidade ou abertura de sentido que lhe permita associar-se a narrativas distintas, até mesmo antagônicas (como foi o caso da fotografia das manifestações em Santiago discutida acima). Quanto ao primeiro aspecto, a despeito de a série "policiais perseguem estudantes com cassetetes" ser bastante característica da década de 1960, a fotografia de Evandro Teixeira tem atributos incomuns. 0 mais singular de todos é sua frontalidade, pois, em função da dinâmica dos conflitos de rua, os fotógrafos costumam se posicionar, por razões de segurança, por trás dos policiais ou fora da "linha de fogo". É o que se observa, por exemplo, em conhecido flagrante do San Francisco Chronicle dos conflitos de rua em Oakland, Califórnia, em 20 de outubro de 1967, no contexto dos protestos contra a guerra do Vietnã ${ }^{10}$.

Quanto ao segundo aspecto, uma questão decisiva ainda não foi enfrentada. Trata-se ou não da morte de um estudante? Na maior parte das vezes em que essa fotografia nos é mostrada ela vem acompanhada de legendas descritivas que remetem à perseguição e à queda do do jovem. No entanto, nas últimas duas décadas começaram a ser frequentes menções à sua morte, tal como sugere, sem contudo afirmá-lo, a narrativa elaborada pela Associated Press. A origem dessa versão é o próprio fotógrafo. Em entrevista a um pesquisador, em 2007, ele afirma que fez "a foto do estudante caindo, um único fotograma, e não deu tempo pra mais nada porque os policiais vieram pra cima de mim" (Fávaro, 2011: 8-9). Em outra entrevista, em 2012, deixa transparecer que houve tempo suficiente para certificar-se de que o estudante havia morrido: "Quando cheguei à Cinelândia eu ainda fotografei aquele estudante de medicina caindo. Ele bateu a cabeça no meio-fio, em frente ao Teatro Municipal, deu um berro horroroso e morreu ali mesmo" (Boni, 2012: 239). Em 2019, em um debate no Museu da República, no Rio de Janeiro, Evandro conta que, ao tentar fugir, o estudante "foi atingido pelo cassetete de madeira de um dos PM". Teria batido com a cabeça no meio-fio e "ficou agonizando na Avenida". E acrescenta que "somente uma semana depois a família teria ficado sabendo de sua morte" (Marques, 2019). No entanto, em depoimento ao site G1 cerca de um ano antes, em 18 de outubro 2018, o fotógrafo admite que os esforços feitos pelo Jornal do Brasil para identificar o estudante e localizar sua família foram infrutíferos. Da mesma forma, não teria sido possível saber se estudante caído havia "sobrevivido" ou não (Marques, 2019). As incertezas em torno dessa imagem são um componente inseparável de seu 
núcleo dramático. 0 fotógrafo permaneceu ou não tempo suficiente junto à cena para observar sua conclusão? O estudante morreu ou não em função da queda? Essa ambiguidade não remete apenas às lacunas da memória, que a tensão do momento certamente exacerbou. Diz igualmente respeito a um dos mais persistentes paradoxos do instantâneo fotográfico: é impossível fotografar o instante em que se morre. Com os braços abertos, em plena queda, depois de atingido pelo inimigo, o estudante de Evandro Teixeira é como o soldado republicano alvejado (ou não) na fotografia de Robert Capa. Um signo de derrota e uma promessa de resistência.

Ao contrário do soldado de Capa, cuja identidade e destino vieram a ser conhecidos muitas décadas depois, nos caso dessa fotografia, a despeito da nitidez das feições do estudante e da notoriedade da imagem, ele permanece um desconhecido que carrega consigo o silêncio de seu "berro horroroso". Mas tal anonimato, ao longo de tanto tempo, contribui para sua força icônica. Uma anedota ajuda-nos a compreendê-lo. Após a prisão do ex-presidente Lula, em 2018, a fotografia de Evandro Teixeira começou a circular nas redes sociais, acompanhada de duas legendas sobrepostas: "Essa foto não tem preço" e "Militares colocando Lula para correr desde 1964" (ou, em outra versão, "o vagabundo do Lula apanhando da polícia"). A operação que permite que esse meme ganhe livre curso não se reduz apenas à coincidência entre as barbas do estudante e as do ex-presidente. Se o estudante não tivesse permanecido anônimo ao longo de décadas, teria sido mais difícil atribuir-Ihe outra identidade, mas é da natureza patética dos foto-ícones que sua força possa ser apropriada e seu sentido redirecionado. Um pequeno detalhe da legenda sobreposta reforça o deslocamento, remetendo a fotografia a 1964 e não a 1968. Ao fazê-lo, sua ancoragem de ilustração célebre da ditadura é mantida, mas ela é descolada do massacre dos estudantes em junho de 1968, passando a associar-se a uma data valorizada pelos setores mais à direita da sociedade, simpáticos ao golpe militar.

A força simbólica dos foto-ícones é, pois, também sua fragilidade. Deslocamentos similares são frequentemente observados nas biografias das imagens, pois suas ressignificações participam das disputas pelo sentido da História. Dificilmente conseguimos ter acesso às passagens que permitem essas transposições, migrações e transmutações de sentido. Este é um desses raros casos em que foi possível localizar uma dessas passagens. Em 7 de dezembro de 2017, cinco meses antes da prisão do ex-presidente Lula, mas quando o inquérito conhecido como "Lava-Jato" já a prenunciava, a revista Veja publica uma nota sob o título: "Justiça torna réus 2 delegados do DEOPS por sequestro na ditadura". Tratava-se da acusação aos responsáveis pela prisão do metalúrgico Feliciano Eugênio Neto em 1975, que teria morrido sob tortura no ano seguinte ${ }^{11}$. Surpreendente- 
mente, a matéria não é ilustrada por fotografia de Feliciano ou de seus algozes, mas pela foto de Evandro Teixeira, cuja relação com a notícia é um disparate. Afinal, o perseguido não é um metalúrgico, mas um estudante; os perseguidores não são agentes da polícia política de São Paulo, mas policiais militares do Rio de Janeiro; e a fotografia é de 1968, e não de 1975.

A conexão entre o uso genérico da fotografia pela Veja, como ilustração da ditadura, e a associação que uma leitura rápida da notícia permite entre um estudante barbado e um jovem metalúrgico perseguido pela polícia (que outro, se não Lula?) pode parecer fortuita. Afinal, a revista resguardou-se legendando a foto corretamente: "Estudante caindo no chão, durante perseguição policial aos manifestantes na Avenida Rio Branco". O crédito a Evandro Teixeira e ao Jornal do Brasil também foi devidamente registrado, mas um engano fatal termina por certificar o vínculo entre a matéria da Veja e o meme da "foto que não tem preço". A revista erra a data da fotografia, indicando-a como tirada em "1964". Esse erro opera aqui como uma "senha" que faculta as demais extrapolações, pois ainda que se conceda 0 benefício de um "ato falho" aos redatores e revisores, manifesta-se nele o desejo de descolar a fotografia de sua referência factual, lançando-a em um circuito mais amplo de associações, substituições e deslizamentos. Como no "trabalho dos sonhos" (Freud, 1981: 516-558), o metalúrgico de 1975 (preso e eventualmente torturado) substitui o estudante de 1968 (em fuga e eventualmente morto), propiciando o deslocamento para o metalúrgico de 2017 (processado e eventualmente preso no ano seguinte).

Em julho de 2020, coroando sua trajetória, essa foto foi escolhida pelo jornal Folha de S. Paulo como símbolo de sua campanha pela democracia. A imagem é publicada na capa da edição impressa, de número 33.330, no dia 4 de julho, quase na mesma posição em que foi publicada no Jornal do Brasil de 22 de junho de 1968, com a seguinte legenda: "A Foto que virou símbolo da repressão militar: imagem de Evandro Teixeira da 'sexta sangrenta' no Rio, um dos atos mais violentos da ditadura contra estudantes. 0 registro faz parte da campanha da Folha pela democracia" (Figuras 8 e 9).

É agora como "símbolo da repressão militar" — e não mais como notícia quente - que ela retorna à primeira página de um jornal. Sua capacidade de sintetizar os antagonistas, a dissimetria das forças e a violência do conflito tornou-a célebre. No entanto, quando o jornal paulista mimetiza a cobertura feita pelo Jornal do Brasil em 1968, não se trata apenas de consagrar uma foto-ícone, mas de reconfigurar a própria história do veículo por meio dela ${ }^{12}$. Que fotos a Folha havia estampado na primeira página naquele sábado subsequente ao massacre? Apenas duas: numa, um cabo da PM "dialoga com jornalistas" de revólver em punho, diante da embaixada americana; na outra, um "popu- 


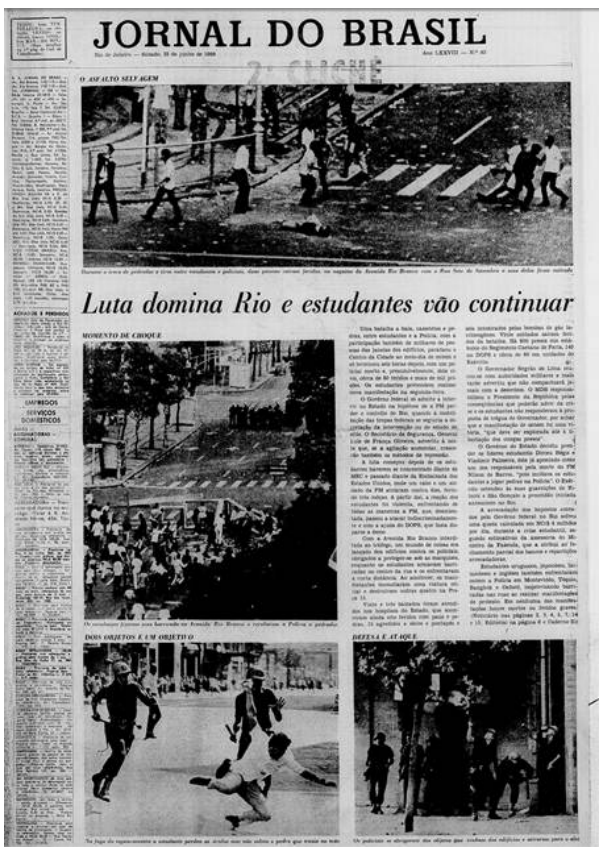

Figura 8 - Capa do Jornal do Brasil, 22 jun. 1968. Fonte: Biblioteca Nacional, Hemeroteca Digital.

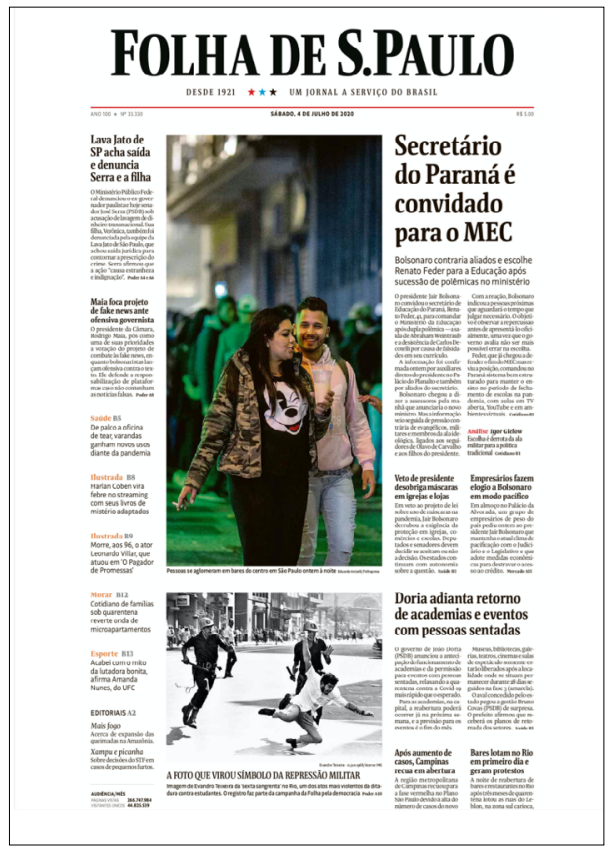

Figura 9 - Capa da Folha de S. Paulo, 4 jul. 2020. Fonte: Arquivo on-line Folha de S. Paulo.

lar" é cercado por "oito soldados" e "preso durante o conflito"13. Ambas, assim como a maioria das fotografias publicadas nas páginas internas, foram fornecidas à Folha pelo Jornal do Brasil. A primeira pode ser vista na página 14 do periódico carioca - a legenda informava que o policial tentava convencer os jornalistas a não relatar que ele havia sido responsável pelo primeiro tiro (isto é, pela ação que fez explodir o conflito nas ruas). Já a prisão do "popular" seria, segundo o Jornal do Brasil, o espancamento de "João Rui Carvalho Soares, 41 anos" que passava pelas proximidades - foto publicada com destaque na primeira página do Caderno $B^{14}$.

A Folha aproveitou várias fotografias enviadas pelo Jornal do Brasil naquela noite (ainda que as tenha publicado sem créditos), mas a foto que elegerá meio século depois como símbolo da "repressão militar" na ditadura ficou de fora". De volta à primeira página onde nunca esteve, sua presença na edição de 4 de julho de 2020 não é apenas um elogio à História e a afirmação de um compromisso com a memória dos crimes da ditadura; tem algo de reparação, que reconfigura o próprio passado do jornal, uma reelaboração de sua cronologia institucional, que agora passa a ser escrita em amarelo (Figura 10). 


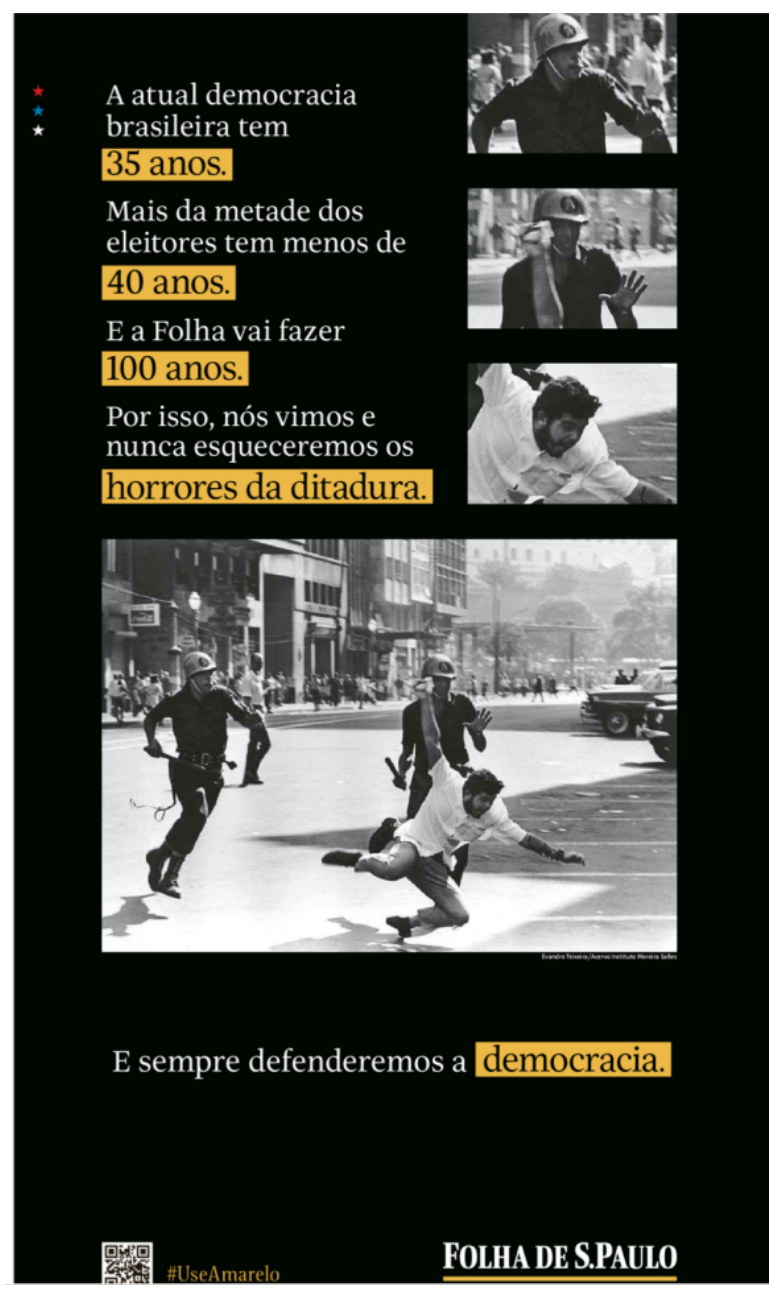

Figura 10 - Folha de S. Paulo, 4 jul. 2020. Fonte: Arquivo on-line Folha de S. Paulo.

Na expressão do estudante, no gesto dos policiais, revemos o que não foi visto e esquecemos o que foi lembrado (mil e uma vezes). Se o valor de um foto-ícone decorre da condensação em uma simples imagem de circunstâncias históricas complexas, sua biografia nos ensina que essa potência, como o sintoma, tem a forma do anacronismo.

Escrito em junho de 2020, mês do $66^{\circ}$ aniversário do golpe de estado na Guatemala e do $52^{\circ}$ aniversário da sexta-feira sangrenta no Rio de Janeiro. Concluído em julho para incorporar a última versão da história... 
Conflitos de interesse: nada a declarar.

Fonte de financiamento: Conselho Nacional de Desenvolvimento Científico e Tecnológico.

Contribuições dos autores: Mauad, A. M.; Lissovsky, M.: Administração do Projeto, Análise Formal, Conceituação, Curadoria de Dados, Escrita - Primeira Redação, Escrita - Revisão e Edição.

\section{NOTAS}

1 Quando esses dois países, entretanto, foram solapados pelas ditaduras militares apoiadas pelo grande irmão do Norte, o Daily Herald já havia encerrado suas atividades.

2 Sobre a possibilidade de biografar imagens, ver Ulpiano Meneses (2002) e Elizabeth Edwards (2002).

3 Seu sucessor imediato, The Sun, operou de 1964 a 1969, quando foi vendido ao magnata da imprensa Rupert Murdoch. 0 arquivo do The Sun, até sua venda, foi incorporado ao acervo de seu antecessor. A equipe do Herald Tribune contou com um dos mais populares fotógrafos da imprensa britânica nas décadas de 1930 e 1940, James Jarché.

40 arquivo não dispõe de índices e não se encontra digitalizado. Observou-se que há imagens relativas ao Brasil em pastas temáticas genéricas, como Café e Futebol, mas não foi possível ainda examiná-las mais detidamente. É bastante provável que algo similar se passe com os demais países, sobretudo com aqueles que não possuem pastas específicas.

50 Daily Herald não a publicou, mas noticiou, em 24 de junho, a queima da efígie de Eisenhower. No Brasil, o Correio da Manhã menciona em 27 de junho de 1954, página 9, "manifestações favoráveis à Guatemala no Chile" organizadas pela associação Amigos da Guatemala e a Central Única dos Trabalhadores do Chile, destacando a participação dos líderes de 'extrema-esquerda" Salvador Allende e Baltasar Castro e do poeta Pablo Neruda.

6 No site da British Library o Daily Herald só foi digitalizado até 1961 e o The Sun, seu sucessor, não se encontra disponível, impossibilitando-nos de verificar se as imagens foram eventualmente publicadas.

7 No início do Governo Costa e Silva foi assinado, em 9 de maio de 1967, o "Convênio de Assessoria ao Planejamento do Ensino Superior" pelo ministro Tarso Dutra, representando o MEC, e por William Ellis, da USAID-Brasil, que confirmava os acordos anteriores. 0 convênio tinha como finalidade "assessorar o trabalho da Diretoria [do Ensino Superior] nos seus 
esforços para atingir a expansão e o aperfeiçoamento, a curto e a longo prazos, do sistema de ensino superior brasileiro, por meio do processo de planejamento que torna possível a preparação e a execução, por parte das autoridades brasileiras, de programas com o objetivo de atender às crescentes necessidades desse setor". Em junho de 1968 o relatório da Equipe de Assessoria ao Planejamento do Ensino Superior, publicado em 1968 pelo MEC, subsidiou 0 grupo de trabalho da Reforma Universitária iniciada em julho desse mesmo ano, cf. Luís Antônio Cunha, Acordo MEC-USAID. Disponível em: <http://www.fgv.br/cpdoc/acervo/dicionarios/ verbete-tematico/acordo-mec-usaid>. Acesso em: 13 ago. 2020.

80 acesso a uma reprodução com definição mais apurada foi impossibilitada pela emergência sanitária da COVID-19, que fechou os serviços de reprodução do arquivo em que a imagem está arquivada.

9 Boa parte de sua equipe acompanhou os acontecimentos que se desenrolaram nas imediações da redação do periódico. Alguns dos cronistas parecem, de fato, descrever os episódios como se os observassem da janela. O próprio Correio da Manhã informa que fotógrafo Rubens Seixas foi agredido a golpes de sabre por policiais e teve seu equipamento pisoteado. Segundo Evandro Teixeira, Erno Schneider também teve o equipamento "apreendido e destruído", assim como Alberto Jacob, do Jornal do Brasil (Fávaro, 2011). Nesse particular, com certeza, a memória de Evandro falha (ou a inferência feita pelo pesquisador que o entrevistou), pois Alberto Jacob foi gravemente ferido pelos policiais da cavalaria em 4 de abril de 1968, na Candelária, após a missa de sétimo dia do estudante Edson Luís. A ação da polícia nesse dia, assim como a agressão ao fotógrafo, também consta dos arquivos do Daily Herald. 0 "68" brasileiro está ainda representado por duas fotografias da invasão do campus da Praia VermeIha na quinta-feira, 20 de junho.

10 Ver: " 1967 Vietnam War protest photos show savagery by police in Oakland". Disponível em: <https://www.sfchronicle.com/chronicle_vault/article/1967-Vietnam-War-protest-photos-show-savagery-by-12338190.php>. Acesso em: 14 jun. 2020. Todos os depoimentos são unânimes em reconhecer que durante os conflitos no Rio de Janeiro não havia lugar seguro para jornalistas e fotógrafos, pois a ira dos policiais também se voltava contra eles.

11 Disponível em: <https://veja.abril.com.br/politica/justica-torna-reus-2-delegados-do-deops-por-sequestro-na-ditadura/ $\geq$. Acesso em: 14 jun. 2020.

12 Sobre os modos da Folha de S. Paulo de inscrever-se nos ciclos narrativos da história contemporânea por meio de uma operação midiográfica, ver Meneses (2016).

13 Folha de S. Paulo, 22 jun. 1968, p. 1. Disponível em: <https://acervo.folha.uol.com.br/ files/flip/8/32/57/18/5185732/original/5185732.jpg $\geq$. Acesso em: 22 jul. 2020. 
14 Em outras fotografias publicadas nos dois jornais, a mesma diferença de tratamento pode ser observada. A Folha opta pela designação genérica (estudante, popular etc.) enquanto o Jornal do Brasil identifica o personagem. Essa diferença conota claramente a decisão editorial de parecer mais "próximo" (este último) ou mais "distante" (a primeira) dos eventos narrados.

15 Entre as possíveis razões, na época, podem ter estado: o Jornal do Brasil reservou-a para si com "exclusividade"; ou, ainda, a Folha evitou uma fotografia que evidenciasse aos leitores a "segunda mão" do material fotográfico que publicava (por isso prefere colocar na primeira página fotos que o primeiro utiliza no interior do jornal).

\section{REFERÊNCIAS BIBLIOGRÁFICAS}

BONI, P. C. A fotografia a serviço da luta contra a ditadura militar no Brasil. Entrevista com Evandro Teixeira concedida a Paulo Boni. Discursos Fotográficos, Londrina, v. 8, n. 12, p. 217-252, jan./jun. 2012. http:// dx.doi.org/10.5433/1984-7939.2012v8n12p217.

EDWARDS, E. Material beings: objecthood and ethnographic photographs. Visual Studies, United Kingdom, v. 17, n. 1, 2002, p. 67-75. https://doi.org/10.1080/14725860220137336.

FÁVARO, A. Ditadura militar - Foto: Evandro Teixeira/JB. In: ENCONTRO NACIONAL DE HISTÓRIA DA MÍDIA, 8., 2001, Guarapuava. Anais [...]. Guarapuava: Unicentro, 28-30 abr. 2011.

FREUD, S. La Interpretación de los sueños. In: FREUD, S. Obras completas: vol. I. Madrid: Biblioteca Nueva, 1981. p. 343-720.

HARIMAN, R.; LUCAITES, J. L. No caption needed. Chicago: University of Chicago Press, 2007.

HOVE, M. T. The Arbenz Factor: Salvador Allende, U. S. - Chilean Relations, and the 1954 U.S. Intervention in Guatemala. Diplomatic History, v. 31, n. 4, p. 623-663, 2007. https://doi.org/10.1111/j.14677709.2007.00656.x.

KRACAUER, S. Photography. In: TRACHETENBERG, A. (ed.). Classic essays on photography. New Haven: Leete's Island Books, 1980. p. 245-268.

LISSOVSKY, M.; AGUIAR, A. L. L. Monumentos à deriva; imagens e memória da ditadura no cinquentenário do golpe militar de 1964. In: ARAÚJO, D. C.; MORETTIN, E. V.; REIA-BAPTISTA, V. (orgs.). Ditaduras revisitadas: cartografias, memórias e representações audiovisuais. 1. ed. Faro: CIAC; Universidade do Algarve, 2016. p. 350-382.

LISSOVSKY, M.; MAUAD, A. M. Orgulho da tortura. Zum, São Paulo, n. 17, p. 88-95, out. 2019.

LOUZADA, S. Prata da casa: fotógrafos e fotografia no Rio de Janeiro. Niterói: Editora da UFF; FAPERJ, 2013.

MARQUES, R. A foto, a história da foto e uma dúvida: quem é esse estudante? O Jornal de Todos os Brasis, 28 ago. 2019. Disponível em: <https://jornalggn.com.br/artigos/a-foto-a-historia-da-foto-e-uma-duvida-queme-esse-estudante-por-rogerio-marques/>. Acesso em: 14 nov. 2020. 
MAUAD, A. M. Foto-ícones, a história por detrás das imagens? Considerações sobre a narratividade das imagens técnicas. In: RAMOS, A. F.; PATRIOTA, R.; PESAVENTO, S. J. (org.). Imagens da História. 1. ed. São Paulo: Hucitec, 2008a. v. 1, p. 33-66.

MAUAD, A. M. Uma disputa, uma perda e uma vitória: fotografia e a produção do acontecimento histórico na imprensa ilustrada dos anos 1950. In: HERSCHMANN, M.; RIBEIRO, A. P. G. Comunicação e História: interfaces e novas abordagens. 1. ed. Rio de Janeiro: Mauad X, 2008b. v. 1, p. 159-189.

MAUAD, A. M. Memórias do contemporâneo, a trajetória de Erno Schneider em foco. Studium, Campinas, n. 27, p. 103-131, 2008c.

MAUAD, A. M. Fotografia pública e cultura visual, em perspectiva histórica. Revista Brasileira de História da Mídia, São Paulo, v. 2, n. 2, p. 11-20, 2013. https://doi.org/10.26664/issn.2238-5126.2220134056.

MENESES, S. Operação midiográfica: o golpe de 1964 e a Folha de S. Paulo. São Paulo: Editora Intermeios, 2016.

MENESES, U. T. B. A fotografia como documento: Robert Capa e o miliciano abatido na Espanha: sugestões para um estudo histórico. Tempo, Niterói, n. 14, p. 131-151, 2002.

STIMSON, B. Introduction. In: STIMSON, B. The pivot of the world: photography and its nation. Massachusetts: MIT Press, 2007. p. 21. 